\title{
Exchange Rate Volatility Effect on Trade Variations in Nigeria
}

\author{
Dr. Oyovwi O. Dickson \\ Ukavwe Andrew \\ Economics Department, College of Education, Warri \\ email:doyovwi@yahoo.com
}

\section{Doi:10.5901/mjss.2013.v4n6p401}

\begin{abstract}
The paper, investigates the hypothesis that exchange rate risk affect international trade. Theoretically and empirically, the results are mix and inconclusive. Our data set that are annual in nature cover the period 1970-2010., were subjected to unit root and cointegration tests Empirical results showed that all variables $I(I)$,except import that is $I(0)$ and are significant at 1,5, and 10 percent. cointegration results revealed that a stable long run equilibrium relationship exists between the variables. Employing error correction modelling, we estimate the equation using ordinary least squares (OLS). The result revealed that exchange rate volatility is insignificant in explaining variations in imports but significant and positive with respect to export. Also, the result showed that exports have positive and significant impact on imports implying that ability to export is hinged importations. This prompted a causality test that rejected the null hypothesis. The study recommends exchange rate and trade policies that will promote greater exchange rate stability and trade conditions that will promote domestic production in the economy. This we believe will enhance non oil exports and reduce importation. To achieve this, government should deliver efficient infrastructural services, especially power supply and other energy resources.
\end{abstract}

\section{Introductory}

Many developing economies like Nigeria have experienced high exchange rate volatility since the implementation of the Structural Adjustment Programme (SAP) that required deregulation of foreign exchange market amongst others. With the SAP conditionality uncertainties enveloped two main monetary policy objectives that policymakers often seek to achieve: price stability and economic growth. Exchange rate volatility refers to short-term fluctuation in exchange rate. These fluctuations could be positive or negative. Either of these is not desirable as it increases the risk or uncertainty in international transaction and thus discourages trade. This view is supported by the International Monetary Fund (IMF) 1984 commissioned study on exchange rate volatility and trade flows and Auboin and Ruta (2011). Volatile real exchange rates are associated with unpredictable movements in the relative prices in the economy. Therefore, exchange rate stability is one of the main factors that promote total investment, price stability and stable economic growth. This is supported by the Asian economies prior to the crisis of the late 1990s.

In Nigeria, exchange rate management has undergone significant changes over the past four decades. In the 1960s Nigeria operated a fixed exchange rate regime fixed at par with the British pound and later the American dollar in addition to restrictions on imports via strict administrative controls on foreign exchange. In 1978, the monetary authorities pegged the naira to a basket of 12 currencies of her major trading partners. The sharp fall in international oil price and consequent decline in foreign exchange receipts in the early 1980s were such that the economy could not meet its international financial commitments, and to mitigate the challenges, the stabilization act of 1982 was implemented which led to accelerated depreciation of the naira. Failure of the Stabilization Act to address the economic problems (unpaid trade bills and accumulation of payment arrears consequent on the sharp fall in oil price) led to the adoption of the Structural Adjustment Programme (SAP) in 1986, aimed amongst others at the realization of a viable and realistic exchange rate, through a flexible arrangement.

The flexible exchange rate regime produced a significant volatility and uncertainty in the exchange rate of the naira. Given the challenges related to data availability and the existence of a multiple exchange rates regime that has been in place in the Nigerian economy since the 1960s, the goal of this paper is to analyze the impact of exchange rate uncertainty on Nigerian trade performance. Exchange rate volatility can affect trade directly, through uncertainty and adjustments costs, and indirectly through its effect on the structure of output, investments as well as on government 
policies. This paper is focused on direct effect the exchange rate exerts on trade. The paper is organized as follows: the next section offer a literature review followed by model specification, and data issue, while section 4 presents and discuss estimation results, finally some concluding evidences are summarized.

\section{Literature review}

There is ambiguity in the literature on the impact of exchange rate volatility on the volume of international trade (Rahmatsyah, Rajaguru and Siregar, 2001). Accordingly, it is an empirical issue which also present diverse results. Generally, two theoretical schools of thought exist that attempt to explain the effect of exchange rate volatility on international trade. They are-:

* The traditional school and

* The risk portfolio school.

The traditional school holds that volatility increases risk of trade and therefore depresses trade flows. Early study of this issue focused on firm's behaviour and presumed that increased exchange rate volatility would increase the uncertainty of profits on contracts denominated in a foreign currency. And this would therefore, reduce international trade to levels lower than would otherwise exist without exchange rate volatility (Farrel, DeRosa and McCown 1983). This uncertainty of profits, would lead risk-averse and risk-natural agents to re-direct their activity from high risk foreign markets to the lower risk home market. A comprehensive review of the literature shows that the traditional school examined not only the presence of risk, but also its degree. And this in turn depends on such factors as whether production inputs are imported, the opportunity to hedge risk and the currency in which contract are denominated.

The risk portfolio school of thought on the other hand postulates that higher risk present greater opportunities for profit and should increase trade. What is referred to as the risk portfolio school is not a united body of thought, but is composed rather of multiple studies varying in complexity, but united in the opinion of the traditional school as unrealistic. De Grauwe (1988) for instance, show how high risk aversion could actually lead to increased exports. According to him, exchange rate volatility unambiguously reduces the total utility to be derived from exporting, but would result in increased exports if the marginal utility of exporting increases (the firm is assumed to be engaged in the domestic market and the export market and allocates output optimally between both markets). Crucial to this result is the idea that the degree of risk aversion is not constant. If it were constant, then exchange rate volatility would unambiguously reduce export, as exporting has become a relatively less attractive activity (substitution effect). There would be no income effect. Alternatively, if the degree of aversion increases, with shrinking income, then the income effect will lead exporters to export even more in response to increased exchange rate volatility. In summary, De Grauwe (1988) argued that the convexity of the profit function ensures that exporters return from favourable exchange rate movement, and the accompanying increased output outstrip the decreased profits associated with adverse exchange rates. Therefore, riskneutral individual will be attracted by these high profit opportunities.

From the foregoing, it is obvious that theory has been unable to provide a definite answer as to whether the trade enhancing effect of portfolio diversification outweighs the costs to risk averse economic agents as exchange rate variability increases. Empirical results from studies of this relationship are similarly inconclusive. They are generally sensitive to the choices of sample period, model specification, form of proxies for exchange rate volatility, and countries considered (developed versus developing). However, when we turn to more recent empirical literature, a certain pattern seems to emerge. It appears that exchange rate volatility has a weak but positive effect on industrialized nations' trade flows while it has a negative and pronounced effect on newly industrialized countries' trade flows. For instance, Baum, Caglayan and Ozkan (2004), relying on a nonlinear specification rather than linear alternatives, show that the effect of exchange rate uncertainty on trade flows is positive yet complex. They also consider the role of income volatility on trade flows among several industrialized countries but its effects are not clear. A subsequent analysis by Grier and Smallwood (2007) reports a significant role for exchange rate uncertainty for developing countries' exports as well as a strong role for income uncertainty in most countries. Their results for developing countries provide support to earlier studies including Arize, Osang and Slottje (2000), Sauer, Bohara (2001) who report negative effects of exchange rate uncertainty on trade flows for developing countries

Cheong, Mehari, Pattichis and Williams (2002) study on exchange rate volatility and U.K exports revealed that exchange rate volatility negatively affects export trade. No evidence was found to support the theoretical proposition that exchange rate uncertainty has a positive impact on international trade. While Aristotelous (2001) finds exchange rate volatility has not had any significant impact on the performance of the British exports to the United States during the 
period of 1889-1999. All in all, the empirical literature has reaffirmed the ambiguous nexus between currency volatility and trade as indicated by the theoretical literature on the subject.

In Nigeria, similar studies on this issue has been carried out like Obiora and Igue (2006), Aliyu (2008) etc. Aliyu 2008 for instance studied the impact of exchange rate volatility on non-oil export using quarterly data while Obiora and Igue 2006 examined exchange rate volatility and U.S-Nigeria trade flows and they showed that exchange rate volatility of the domestic currency has a negative and significant effect on Nigeria's exports to the United States of America. This study departs from the foregoing by using total export and import and not restricted to a particular country. This study will provide evidence on the effect of exchange rate risk on the imports, exports and total trade of Nigeria. Knowledge of the degree to which exchange rate risk affect Nigerian trade is important for the design of both exchange rate and trade policies.

\section{Data and Methodology}

There are two primary determinants of import/export demand as noted by Dornbusch (1988), Hooper and Marquez (1993). First is the foreign income variable, which measures the economic activity (income effect). Second, is the relative price or terms of trade variable. We replaced these primary determinants with oil price (income effect) and external reserve considering the mono cultural nature of the Nigerian economy that is oil driven. In addition, we incorporate exports and imports in the import and export models and is done to effect both variables have on each other. Exchange rate volatility is an additional variable added to the traditional model of trade to measure its effect on Nigeria's imports and exports (volatility effect). Incorporating the above, we have an augmented traditional model of import and export demand:

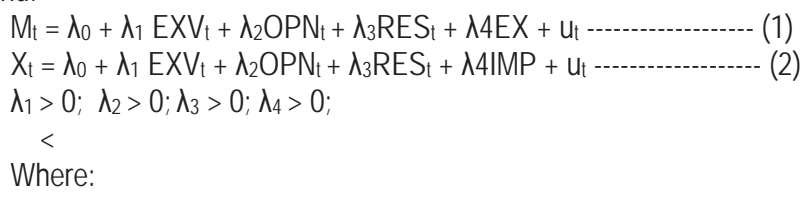

$X_{\mathrm{t}}=\lambda_{0}+\lambda_{1} \mathrm{EXV}_{\mathrm{t}}+\lambda_{2} \mathrm{OPN}_{\mathrm{t}}+\lambda_{3} \mathrm{RES}_{\mathrm{t}}+\lambda 4 \mathrm{IMP}+\mathrm{u}_{\mathrm{t}}$

$\lambda_{1}>0 ; \lambda_{2}>0 ; \lambda_{3}>0 ; \lambda_{4}>0$;

$<$

Where:

$\mathrm{i}=0,1,2,3,4$

$\lambda_{\mathrm{i}}=$ coefficients to be estimated

$M_{t}$ and $X_{t}$ are real import/export values defined as nominal import/export deflated by the consumer price index. EXV is exchange rate volatility OPN $\mathrm{N}_{t}$ oil price in domestic currency, RES is external reserve. The data are annual data extracted from the central bank of Nigeria statistical bulletin .

Exchange rate volatility can be measured in three ways (Schnabl 2007). First, oscillations around a constant level as measured by the standard deviation of percent exchange rate changes $(\sigma)$ can be seen as a proxy for uncertainty and transactions costs for international trade and short-term capital flows. Second, the arithmetic average of percent exchange rate changes $(\mu)$ can be seen as a measure for changes in the exchange rate level. Thirdly, sustained appreciation or depreciation can be captured by the yearly relative exchange rate change $(\mathrm{T})$ comparing January with December. This study will use the second method and also measure the impact of exchange rate volatility using Generalised Autoregressive Conditional Heteroskedasticity (GARCH). This is to ascertain if the two approaches will give the same result.

The time series characteristics of the variables are investigated to determine their levels of integration. This is done by applying the augmented Dickey-Fuller (ADF) tests. The essence is to ascertain whether the underlying stochastic process that generated the series can be assumed to be invariant with respect to time (Pyndyck and Rubinfied, 1998). The ADF is specified when $\mathrm{S}_{t}$ is autoregressive to eliminate serial correlation of errors and it takes the form:

$$
\Delta y_{t}=\operatorname{ayt-1}+\sum_{i=1}^{m} \beta \Delta y_{t-1}+\delta+y t+\varepsilon t
$$

\section{Analysis of result}

Prior to the estimation of the error correction model, time series stationary is tested through Augmented Dickey-Fuller test and order of integration defined. The unit root test results are presented below. The result showed that all variables are found to be I(I),except import that is I(0) and are significant at 1,5, and 10 percent. 


\begin{tabular}{|c|c|c|c|}
\hline & \multicolumn{2}{|c|}{ Intercept } & \multirow[b]{2}{*}{$\mathrm{Lag}$} \\
\hline & $\mathrm{I}(0)$ & $\mathrm{I}(\mathrm{l})$ & \\
\hline EX & -2.9031 & -2.9881 & 1 \\
\hline EXV & -4.1844 & -7.1389 & 1 \\
\hline IMP & 5.2553 & -2.3046 & 1 \\
\hline OPN & 1.5064 & -2.8406 & 1 \\
\hline RES & -1.8028 & -2.9694 & 1 \\
\hline \multicolumn{4}{|c|}{ Test critical values } \\
\hline $1 \%$ & -3.6067 & -3.6117 & \\
\hline $5 \%$ & -2.9378 & -2.9399 & \\
\hline $10 \%$ & -2.6069 & -2.6080 & \\
\hline
\end{tabular}

Computed by author using E-View 3.0

To establish the existence of long run relationship among the variables, Johansen method was used. The result showed long run relationship. We estimated the error correction model using the ordinary least squares (OLS) method. The results are presented below presented below:

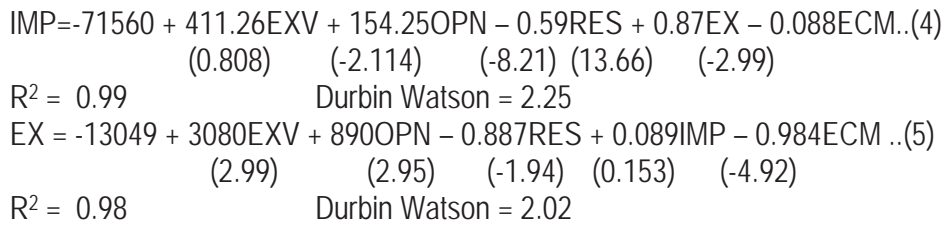

The estimated coefficients of equations 4 and 5 showed that exchange rate volatility is insignificant in explaining variations in imports but significant and positive with respect to export. This partially conform to Aliyu 2008 and Obiora and Igue (2006) similar study on Nigerian exports and Fang et al (2005) study of Asian economies. The nature of Nigeria's imports and export that are mainly capital equipment and oil explains the result. The coefficient of the error correction term (ECM) is white noise, normally distributed and homoskedastic. Its significance and right sign validates the cointegration relationship in the import/export models. The result also revealed that exports has positive and significant impact on imports implying that ability to export is hinged importations. Happenings in the oil sector and the real sector that are dependent on foreign inputs explain the result. This prompted a causality test (see appendix) and the result rejected the null hypothesis. The sign and significance of oil price in the two models, underscore the reliance of the economy on oil.

The $\mathrm{R}^{2}$, value is of 0.99 and 0.98 for import and export respectively. This means that the variables in the regression equation explain more than 90 percent of all variations in imports/exports in Nigeria for the period 1970 to 2010. The Durbin-Watson (DW) test statistic $\left(d^{*}\right)$ shows the absence of first order serial correlation between the error terms. From the result $d^{*}$ is greater than 2 . We therefore accept the null hypothesis $\left(\mathrm{H}_{0}\right)$, which says that there is no positive autocorrelation of the errors' terms; we reject the alternative hypothesis $\left(\mathrm{H}_{1}\right)$, which says that there is positive weak autocorrelation of the errors' terms.

\section{Conclusion}

In this paper, we investigated the effect of exchange rate volatility on trade in Nigeria using error correction model. We found that exchange rate risk is positively related to import/export but insignificant/significant in explaining variation in import/export respectively. The extent of this effect depends on a number of factors, including the existence of hedging instruments, the structure of production, nature of imports/export, and the degree of economic integration across countries. The ECM results of -2.99 and -4.92 confirm that imports/ exports in Nigeria has an automatic adjustment mechanism and they responds to deviations from equilibrium in a balancing manner.

The policy implication of the result hinged on the need to diversify the economy and encourage domestic production of commodities that we are capable of producing like petroleum products amongst others. In this regards, the study recommends the exchange rate and trade policies that will promote greater exchange rate stability and trade 
conditions that will promote domestic production in the economy. This we believe will enhance non oil exports and reduce importation. To achieve this, government should deliver efficient infrastructural services, especially power supply and other energy resources.

\section{References:}

Aliyu, Shehu Usman Rano (2008) 'Exchange rate volatility and export trade in Nigeria: an empirical investigation' Munich Personal RePEc Archive.

Aristotelous, K. (2001)."Exchange rate volatility, exchange rate regime, and trade volume: evidence from the UK-US export function (1889-1999)", Economic Letters, 72, pp.87-94.

Arize C, Osang T, , Slottje D. J (2000).'Exchange rate volatility and foreign trade: Evidence from thirteen LDCs'. Journal of Business and Economic Statistics, 18, 10-17.

Baum C. F, Caglayan M, , Ozkan N (2004). 'Nonlinear effects of exchange rate volatility on the volume of bilateral exports'. Journal of Applied Econometrics, 19,1-23.

Chongcheul Cheong, Tesfa Mehari, Charalambos Pattichis and Leighton Vaughan Williams (2002) discussion paper Department of Economics and Politics The Nottingham Trent University Burton Street Nottingham NG1 4BU U.K

DeGrauwe, P. (1988) "Exchange rate variability and the slowdown in growth of international trade." International Monetary Fund Staff Papers, 35, 63-84.

Dornbusch R. (1988) Exchange Rate and Inflation. MIT Press: Cambridge U.K.

Fang, WenShwo; Lai, YiHao; and Miller, Stephen M (2005) "Does exchange rate risk affect exports asymmetrically? Asian evidence" Economics Working Papers. Paper 200509. http://digitalcommons.uconn.edu/econ_wpapers/200509

Farrel Victoria S., Dean A. De Rosa and F Ashby Mclown (1983) "Effect Of Exchange Rate Volatility on International Trade and Other Economic Variables: A Review Of The Literature" Staff Studies No. 130 United States Of America Board of Governors of The Federal Reserve Bank System, December.

Grier K. B , Smallwood A. D (2007). 'Uncertainty and export performance: Evidence from 18 countries'. Journal of Money, Credit and Banking, 39, 965-979.

Hooper, P. And J Marquez (1993)" Exchange Rate, Prices and External Adjustment In The United States and Japan" International Finance Discussion Paper No. 456. Board of Governors of Federal Reserve System

International Monetary Fund. (1984) "Exchange rate volatility and world trade" Washington D.C.

Marc Auboin and Michele Ruta(2011) 'The relationship between exchange rates and international trade: a review of economic literature' World Trade Organization(WTO).

Obiora, K.I and Igue, N.N (2006). 'Exchange rate volatility and U.S-Nigeria trade flows: An econometric appraisal of the evidence.' Paper Presented at the $11^{\text {th }}$ Annual Conference of the African Econometric Society. $5^{\text {th }}-7^{\text {th }}$ July. Dakar, Senegal

Rahmatsyah, T, G. Rajaguru and R. Siregar (2001). "Exchange rate volatility, trade and "Fixing for Life" in Thailand", mimeo (October).

Sauer C, Bohara A (2001). 'Exchange rate volatility and exports: regional differences between developing and industrialized countries'. Review of International Economics, 9, 133-152.

\section{Appendix}

Table 1: OLS result for import

Dependent Variable: IMP

Method: Least Squares

Date: 04/04/13 Time: 11:48

Sample(adjusted): 19732010

Included observations: 38 after adjusting endpoints

\begin{tabular}{lllll}
\hline \hline Variable & Coefficient & Std. Error & t-Statistic & Prob. \\
\hline \hline EXV & 411.2529 & 509.0309 & 0.807913 & 0.4251 \\
OPN & 154.2521 & 72.96919 & 2.113934 & 0.0424 \\
RES & -0.590719 & 0.071946 & -8.210624 & 0.0000 \\
EX & 0.872160 & 0.063844 & 13.66090 & 0.0000 \\
ECN & -0.087715 & 0.029382 & -2.985295 & 0.0054 \\
C & -71560.18 & 37720.02 & -1.897140 & 0.0669 \\
\hline \hline R-squared & 0.993389 & Mean dependent var & 1183387. \\
Adjusted R-squared & 0.992356 & S.D. dependent var & 2008850. \\
S.E. of regression & 175633.9 & Akaike info criterion & 27.13413 \\
& & & &
\end{tabular}




\begin{tabular}{llll} 
Sum squared resid & $9.87 \mathrm{E}+11$ & Schwarz criterion & 27.39270 \\
Log likelihood & -509.5485 & F-statistic & 961.6780 \\
Durbin-Watson stat & 2.254593 & Prob(F-statistic) & 0.000000 \\
\hline \hline
\end{tabular}

Table 2: OLS result for export

Dependent Variable: EX

Method: Least Squares

Date: 04/04/13 Time: 15:28

Sample(adjusted): 19802010

Included observations: 31 after adjusting endpoints

Convergence achieved after 16 iterations

\begin{tabular}{lllll}
\hline \hline Variable & Coefficient & Std. Error & t-Statistic & Prob. \\
\hline \hline OPN(-5) & 890.8114 & 302.0506 & 2.949212 & 0.0070 \\
RES(-4) & -0.887303 & 0.456299 & -1.944567 & 0.0636 \\
IMP(-5) & 0.089263 & 0.582767 & 0.153170 & 0.8795 \\
EXV(-2) & 3080.029 & 1102.718 & 2.793124 & 0.0101 \\
ECM(-6) & -0.983827 & 0.199982 & -4.919570 & 0.0001 \\
C & -1304893. & 1023976. & -1.274339 & 0.2147 \\
AR( & 1.134238 & 0.070813 & 16.01743 & 0.0000 \\
$1)$ & & & \\
\hline \hline R-squared & 0.982896 & Mean dependent var & 2328319. \\
Adjusted R-squared & 0.978620 & S.D. dependent var & 3412617. \\
S.E. of regression & 498993.7 & Akaike info criterion & 29.27425 \\
Sum squared resid & $5.98 E+12$ & Schwarz criterion & 29.59806 \\
Log likelihood & -446.7509 & Durbin-Watson stat & 2.023789 \\
\hline \hline Inverted AR Roots & 1.13 & \\
& \multicolumn{5}{l}{ Estimated AR process is nonstationary } \\
\hline \hline
\end{tabular}

Table 3: Causality result

Pairwise Granger Causality Tests

Date: 04/07/13 Time: 16:53

Sample: 19702010

Lags: 2

\begin{tabular}{llcc}
\hline \hline Null Hypothesis: & Obs & F-Statistic & Probability \\
\hline \hline IMP does not Granger Cause EX & \multirow{2}{*}{39} & 0.75263 & 0.47881 \\
EX does not Granger Cause IMP & & 6.48044 & 0.00413 \\
\hline \hline
\end{tabular}

